\title{
GERAKAN ISLAM RADIKAL DAN TERORISME DI INDONESIA: KAJIAN TERHADAP UPAYA INTEGRASI BANGSA*
}

\author{
Istadiyantha; M. Farhan M; Eva Farhah \\ istayn@gmail.com \\ Jurusan Sastra Arab Fakultas Sastra dan Seni Rupa UNS \\ dan Pusat Studi Ekonomi Islam LPPM UNS
}

\begin{abstract}
Research on Radical Islamic Movement and Terrorism in Indonesia: Study of Integration Efforts against Nations will review the symptoms and done by a group of religious communities in prioritizing some of the principal teachings of his religion and studied violence and intimidation from the perspective of religious teachings. How is ideology behind the acts of violence and terrorism, and how the views of religious leaders against the ideology. On the other hand, it is also assessed the strengths and weaknesses of the government in overcoming the action. It will be found the rules that can be used as a guide for policy makers to undertake preventive measures.
\end{abstract}

This research is useful in politic, sociology and religious field. This research would be useful to inform the public about the ideology and worldview of radical Islamic movements and terrorism, and its relation to nation integration. Understanding of the nation's character is very important to help the realization of national security system. A country having a good separation in nation's character will have positive steps to anticipate the problems of national security.

Keywords: radical movement, radicalism, terrorism, nation integration

$$
\text { ملخصص }
$$

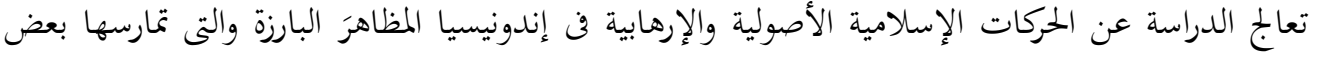

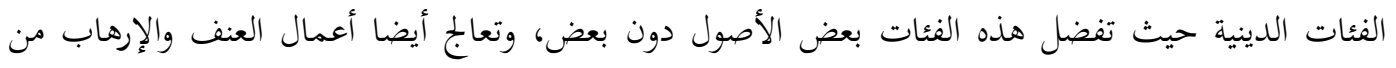

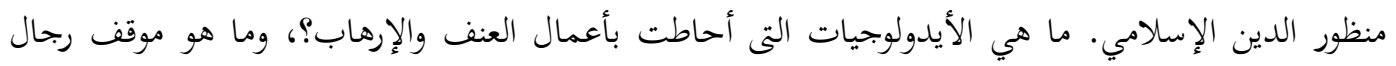

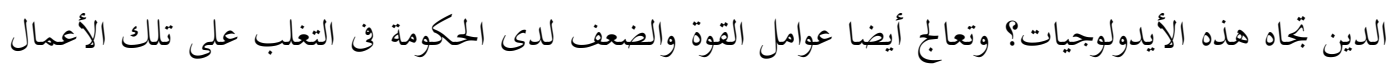

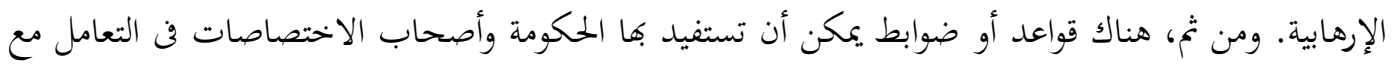

$$
\begin{aligned}
& \text { هذه الأعمال كوسيلة وقائية . } \\
& \text { وهذه الدراسة تؤتى ثمارها في حقل العلوم السياسية، والاجتماعية، والدينية. ومن المتوقع أن تقدم هذه }
\end{aligned}
$$

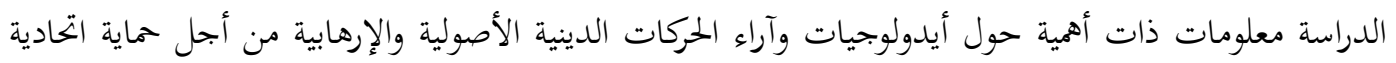

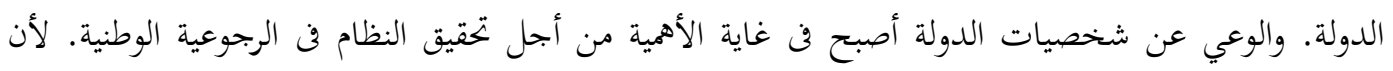

$$
\begin{aligned}
& \text { الدولة التى لديها الوعي العميق فن شخصيات شعوبها ستمضى خطوات صحيحة في التغلب على مختلف المشاكل } \\
& \text { في الرجوعية الوطنية . } \\
& \text { الكلمات الدليلية: جذور الحركات، الأصولية، الإرهابية، اتحادية الدولة }
\end{aligned}
$$

* Artikel Publikasi Ilmiah Penelitian Hibah Unggulan Madya LPPM UNS 2013. 


\section{Pendahuluan}

Proses pembentukan persatuan bangsa Indonesia menurut pengalaman sejarahnya, bukan secara kebetulan, ideologi masyarakat yang dicita-citakan terpampang dalam lambang negara Republik Indonesia Bhinneka Tunggal Ika, 'berbeda-beda namun satu jua'. Semboyan ini berakar dari sejarah pada masa kerajaan Majapahit, diangkat dari karya kakawin Sutasoma ciptaan Empu Tantular, menggambarkan berkembangnya agamaagama, sekte-sekte agama, dan kepercayaan yang berbeda-beda, namun hidup berdampingan secara damai, karena hakikatnya satu: menyembah Tuhan Sang Pencipta

(Poerbatjaraka,1957:40-45). Demikian pula dengan bangsa Indonesia yang berasal dari suku bangsa yang beraneka ragam dan banyak keberagaman lain yang melekat pada dirinya.

Keberagaman, atau lebih lazim disebut perbedaan yang dimiliki bangsa ini meliputi antara lain wilayah kepulauan yang tersebar di antara kawasan-kawasan laut di Nusantara, geografi, ekologi, sistem mata pencaharian, ratusan budaya etnis atau lokal, agama, kepercayaan, dan bahasa (Wertheim, 1999:1-10; Koentjaraningrat, 1971). Di samping keberagaman atau perbedaan, berbagai suku bangsa di Indonesia juga memiliki beberapa kesamaan.

Bagi Gerakan Islam Radikal, kesamaan-kesamaan itu bukan satusatunya alat pengikat persatuan, karena menurut keyakinan mereka, ikatan yang paling kuat adalah atas dasar kesamaan keyakinan dan keimanan. Gerakan Radikal Islam dan terorisme telah memiliki jaringan dan teknologi yang modern, sehingga cara-cara penanggulangan yang konvensional dengan cara lama sangat dikhawatirkan kehandalannya, oleh sebab itu perlu dikaji lebih mendalam upaya integrasi bangsa Indonesia yang lebih memadai.

\section{Akar Gerakan Islam Radikal}

\subsection{Pengertian Gerakan Islam Radikal}

Menurut Sartono Kartodirdjo, radikalisme keagamaan adalah gerakan keagamaan yang berusaha merombak secara total tatanan politis atau tatanan sosial yang ada dengan menggunakan kekerasan (Kartodirdjo, 1985:38). Radical adalah 'of or from the root or base (Hornby, 1987: 691); fundamental; (politics) favouring fundamental reforms; advanced in opinions and politics; (maths) relating to the root of a member or quantity' (Hornby, 1987: 350). Sedangkan millitant artinya 'ready for fighting; actively engaged in or supporting the use of force or strong pressure' (Hornby, 1987: 536). Dan di dalam The American Heritage Dictionary of English Language disusun oleh William Morris bahwa gerakan keagamaan yang berciri militan atau radikal, aktivitasnya selalu bersifat agresif, siap berjuang, bertempur, berkelahi atau berperang, terutama untuk memperlihatkan pengabdian mereka secara total terhadap suatu cita-cita (Morris, 1973: 832). Sebagai contoh dari salah satu karakteristik perjuangan yang total itu sering muncul semboyan yang tegas seakan tidak dapat ditawar lagi, seperti semboyan gerakan Ikhwanul Muslimin (berdiri di Mesir, 1928); 'Isy kariman au mut syahìdan, artinya 'Hiduplah mulia, atau matilah syahid!', dan ada pula semboyan dari gerakan revolusi Iran (1979): Nab syarq, nab gharb, faqat jumhūri-I Islāmi, artinya 'Bukan Timur dan bukan Barat, hanyalah Republik Islam' (Rais, 1990: 38). Kecuali itu masih ada beberapa penyebutan bagi Islam fundamentalis, kadang disebut dengan "restitutionist" dan kadang juga "restorationist", sesuai dengan alasan berikut:

Muslim fundamentalist have also been called "restitutionist" and "restorationist" because they constantly strive to recreat an Islamic state founded on the same fundamental 
principles as the first Islamic state which was established in $622 A D$ by Prophet Muhammad in Medina (and then continued by the Khulafah-i Rashidin (Husain, 1997: 99).

Ada dua tipe gerakan Islam radikal saat itu, pertama gerakan Islam radikal kritis; kedua gerakan Islam radikal fundamentalis (Ngatawi, 2002: 54). a. Gerakan Radikal Islam Kritis: gerakan ini terjadi karena ada tekanan sosial, kesewenang-wenangan, dan ketidak-adilan yang dilakukan oleh pemerintah kolonial/ penjajah. Gerakan radikal jenis ini terjadi bukan karena dorongan ideologi Islam, gerakan ini bukan karena didorong suatu cita-cita untuk menegakkan nilai-nilai Islam, atau bukan sebagai suatu perjuangan untuk penyebaran ajaran Islam, tetapi karena adanya perlawanan terhadap tatanan yang tidak adil, tekanan penguasa ini langsung bersinggungan dengan kepentingan masyarakat. b. Gerakan Radikal Islam Fundamentalis: proses terjadinya gerakan ini sama seperti gerakan yang pertama tadi, hanya saja orientasi, misi, dan pendekatannya berbeda dengan gerakan Islam radikal kritis. Gerakan ini lebih bersifat sebagai suatu gerakan ideologis daripada gerakan sosial, gerakan ini lebih mementingkan tertanamnya ideologi keislaman dalam struktur sosial daripada mewujudkan terjadinya perubahan sosial. Karena karakter dari gerakan ini sedemikian rupa, maka gerakan ini tidak saja hanya ditujukan kepada kelompok di luar Islam, tetapi juga kepada sesama umat Islam yang berbeda pemahamannya terhadap Islam, sehingga gerakan ini tidak segan-segan untuk melawan sesama pemeluk Islam yang dianggap sesat dan menyimpang (Ngatawi, 2002: 60).

Di pihak lain Al-Ushūliyyah juga disebut sebagai skripturalis, legalis, dan literalis.

Muslim fundamentalists constitute the largest and most conspicuous category of Islamic revivalists or Islamists. They are referred to as "scripturalists", "legalists", and "literalists" because they advocate rigid adherence to the fundamentals of Islam, as literally interpreted from the Quran and the Sunna (Prophet Muhannad's sayings and deeds). They often strive to establish an Islamic state based on the rigorous implementation of the shariah and insist that the five faraidh (duties) be scrupulously adhered to by all their coreligionists.

(Lihat: Husain, 1997: 97-127)

dan Liddle, 1998: 283).

Pendapat yang lebih baru adalah istilah yang ditawarkan oleh Oliver Roy, ia membedakan antara fundamentalisme dan neofundamentalisme, Selama tahun 1980an terdapat pergeseran dari Islamisme politik ke neofundamentalisme. Kaum militan yang dulunya berjuang untuk revolusi Islam, kini terlibat dalam proses re-Islamisasi dari bawah (Roy, 1996: 9698). Dikatakan pula bahwa mereka berkampanye prosyariat, melakukan gerakan secara intelektual, keterlibatan dalam politik, dan peran professional mereka dalam masyarakat modern, gerakan demikian juga dilakukan oleh organisasinya Hasan Al-Banna. Gerakan mereka mirip para mullah (syiah) tradisional, yang dari sedikit demi sedikit menemukan kembali inspirasi formalism yang selalu hidup di kalangan pendirinya, yang merupakan perpaduan yang rapuh antara Islam dengan modernitas politik, pada akhirnya tak pernah mengakar (Roy, 1996: 96).

Istilah "Fundamentalisme" sebagai suatu konsep sangat sarat dengan steorotipe Barat dan konstruk pemikiran Kristen, yang menyiratkan ancaman monolitik yang sebenarnya tidak ada (Yunanto dkk., 2003: 18). Dikatakan pula oleh Yunanto bahwa Esposito kemudian mengajukan penggunaan istilah yang lebih 
umum, yaitu Islam Politik (Political Islam) dan Islamisme lebih umum digunakan. Istilah yang diajukan oleh Esposito ini dalam konteks Indonesia lebih cocok dilekatkan kepada gerakan-gerakan Islam yang mengusung nilai Islam dengan tujuan untuk mengubah norma yang berlangsung dalam suatu masyarakat yang tidak oposisional terhadap kekuasaan, tetapi memakai koridor perdamaian (Yunanto dkk., 2003: 18). Tetapi di pihak lain telah disepakati oleh kalangan ahli politik Indonesia, bahwa yang dimaksud oleh Yunanto tadi adalah istilah "Politik Islam", sedangkan istilah yang merupakan padanan dari Islam Fundamentalisme atau Islam militan adalah "Islam Politik" (bdk. Roy: 1996). Di pihak lain, Youssef Choueir mengatakan dalam Hamzawi (2012: 10) Politik Islam dapat didefinisikan sebagai teori politik dalam pandangan Islam, yaitu simbol-simbol dan nash-nash dari agama Islam yang berkisar pada ketertiban sosial, kekuasaan, dan autoritas. Dengan kata lain, Politik Islam merupakan bentuk politik identitas yang memandang Islam sebagai din dan daulah (agama dan negara).

Islam Politik adalah institusi politik yang orientasinya adalah mengusung Islam sebagai pedoman kehidupan masyarakat dan sistem politik negara dan berjuang untuk menerapkan syariat Islam dalam negara-negara bermayoritas Muslim atau mewujudkan sebuah negara Islam secara legal-formal maupun secara substansial berdasarkan interpretasi terhadap Alquran, Sunnah, dan sejarah Khilafah Islam setelah wafatnya Nabi Muhammad. Berdasarkan itu, label Islam Politik mencakup semua kekuatan-kekuatan politik yang memiliki orientasi dan upaya agar agama Islam tidak dipisahkan dari sistem politik negara dan kehidupan masyarakat, bahkan tidak dipisahkan dari sistem politik di seluruh dunia Islam (negara-negara bermayoritas Muslim) (Hamzawi, 2012: 10).

\subsection{Gerakan Islam Radikal di Timur Tengah}

Apa yang dilakukan oleh kelompok fundamentalisme Islam sebenarnya merupakan upaya meneruskan cita-cita gerakan yang digagas oleh para tokoh terdahulu (Abegebriel, 2004: 235-236). Dalam ranah sejarah, munculnya gerakan fundamentalisme Islam merupakan kelanjutan dari gerakan Khawarij pada zaman Khalifah Ali Bin Thalib, gerakan ini sebagai gerakan yang memiliki karakteristik radikal dan fundamentalisme Islam klasik, yang mempengaruhi gerakan fundamentalisme di sepanjang sejarah (Syarkun dan Ghorara, 2004: 451).

Sesungguhnya kaum Khawarij dikenal bengis dan kasar, mereka sangat keras dan bengis terhadap muslimin, bahkan kekasarannya sampai pada derajat tercela, yaitu menghalalkan darah dan harta kaum muslimin serta kehormatannya, mereka juga membunuh dan menyebarkan ketakutan di tengah-tengah kaum muslimin. Adapun para musuh Islam murni dari kalangan penyembah berhala dan lainnya, dibiarkan, diabaikan, serta mereka tak disakitinya (www. wahonot.wordpress.com. 2008: 9-10). Maka Rasulullah telah mengisyaratkan dalam sebuah Hadis bahwa "Mereka (para kaum khawarij) ini suka membunuh orang Islam dan membiarkan para penyembah berhala (H.R. Bukhari,VI: 376 no. 3644; H.R. Muslim, II: 42 no. 1064).

Jika tindakan radikal itu
diidentikkan fundamentalisme, maka Syeh Zaid bin Muhammad mengatakan bahwa gerakan terorisme (kekerasan) dalam Islam sudah berlangsung sejak lama, sejak masa awal Islam. Syeh Zaid menyebut kasus-kasus pembunuhan terhadap khalifah Umar, Utsman, Ali, dan berbagai pemikiran Qadariyah serta Mu'tazilah merupakan tindakan yang dapat dikategorikan teroris (Syarkun dan.Ghorara, 2004: 473).

Pendapat di atas dikuatkan oleh Azyumardi Azra bahwa gerakan Khawarij merupakan Gerakan Fundamentalisme 
Islam klasik yang pada gilirannya mempengaruhi banyak gerakan fundamentalisme Islam sepanjang sejarah. Gerakan Khawarij yang muncul dari pertikaian Khalifah Ali bin Abi Thalib dengan Mu'awiyah bin Abi Sufyan, terkenal dengan prinsip-prinsip radikal dan ekstrim, bagi mereka ada prinsip bahwa tidak ada hukum kecuali hukum Allah (Azra, 1996: 111)

Akar gerakan fundamentalis berikutnya adalah Gerakan Salafi. Asal kata salaf secara bahasa bermakna 'orang yang telah terdahulu, dalam ilmu, iman, keutamaan, dan kebaikan (Ramly, 2006: 286). Ibnu Mandzur mengatakan bahwa "salaf" adalah orang-orang terdahulu dari para nenek moyang yang perilakunya utama, yang mempunyai hubungan kekerabatan dengan generasi pertama para tabiin, yakni terdiri dari pengikut para sahabat Nabi yang disebut dengan Salafush-shalih (Ibnu Mandzur, tt: 159). Istilah salafush-shalih merujuk perkataan Rasulullah saw. kepada puterinya Fathimah bahwa "sebaik-baik pendahulu atau salaf adalah aku (Rasulullah)". dan pada kesempatan lain Rasulullah berkata kepada Zainab bahwa: "Susullah salafushshalih atau pendahulu kita dari orangorang shalih, yaitu Utsman Bin Masdz'un (H.R. Muslim 2450). Golongan yang disebut sebagai salafush-shalih adalah generasi yang dianggap sebagai generasi pertama, yang masih murni meneladani Rasulullah saw., para tabiin, dan tabiin tabiin (Ramly, 2006: 290). Hal ini merujuk pada Hadis Nabi "Sebaik-baik manusia adalah generasiku, kemudian generasi sesudahnya, kemudian generasi sesudahnya lagi, kemudian datanglah kaum yang syahadahnya salah, seorang dari mereka mendahului sumpahnya, dan sumpahnya mendahului syahadahnya" (H.R. Bukhari dan Muslim). Hubungan istilah Salafiyah menyangkut konteks historis yang dikaitkan dengan kehidupan Islam pada zaman Rasulullah, para sahabat, tabiin, dan tabiin-tabiin. Kata Ibnu Taimiyah (1263-1328) bahwa: "Tidak tercela sikap orang yang menampakkan dirinya bermanhaj salaf, menisbatkan diri dan bangga dengan sebutan tersebut, bahkan pernyataan itu wajib diterima menurut kesepakatan ulama, sebab mazhab salaf tidak lain adalah kebenaran (Taimiyyah, tt: 149).

Pada masa berikutnya, gerakan fundamentalis Islam pra-modern pertama, yang selanjutnya menjadi prototipe banyak gerakan fundamentalis Islam muncul di Semenanjung Arabia, di bawah pimpinan Muhammad bin Abdul Wahhab (17931792). Gerakan ini banyak dipengaruhi gagasan-gagasan pembaharuan Ibnu Taimiyah dan memperoleh pendidikan di kalangan ulama reformis di Haramayn, dan dengan tampilnya tokoh Ibnu Abdul Wahhab ini gerakan Wahabi berhasil mengusung tema memurnikan Islam dari takhayul, bid'ah, dan khurafat dan mendorong gerakan ini menjadi radikal. Dalam melancarkan gerakannya Ibnu Abdul Wahhab melakukan korporasi dengan Ibnu Sa'ud. Keduanya menggemakan seruan jihad kepada kaum muslimin dan menghancurkan segala bentuk praktik keagamaan yang dianggap telah menyimpang dari ajaran Islam yang murni. Gerakan ini bukan sekedar purifikasi tauhid, tetapi juga melakukan penumpahan darah di Mekah dan Medinah yang diikuti dengan penghancuran monumen historis yang dipandang sebagai simbol penyimpangan agama. Gerakan yang kurang lebih sama juga terjadi di Nigeria Utara, Minangkabau (Sumatera Barat), anak Benua India, Sudan, dan Somalia (Azra, 1996:. 112).

Sepeninggal Nabi Muhammad Saw., kepemimpinan diteruskan oleh "Khulafa'ur Raasyidin", yaitu empat sahabat Rasul yang menjadi pilihan. Pada kehidupan kenegaraan di masa empat sahabat, hanya ada satu kepala Negara yaitu Abubakar Ash-Shiddiq (632-634 M.) yang meninggal dunia dengan wajar, tanpa disebabkan oleh pertikaian atau pertumpahdarahan. selain itu, Umar IbnulKhattab (memerintah 634 - 644 M.) 
dibunuh oleh budak Kristen milik gubernur Basrah. Ketiga, Utsman Ibnu 'Affan (644656 M.) terbunuh dan rumahnya dijarah oleh orang yang menganggap pemerintahannya tirani. Khalifah yang terakhir, yaitu Ali Ibnu Abi Thalib (656 661 M.) menantu Nabi, terbunuh dalam perjalanannya menuju masjid pada saat masyarakat Islam terpecah belah oleh perselisihan (Eickelman dan Piscatori, 1998: 46).

Sebab tumbuhnya militan Islam atau Gerakan Islam Politik, pertama adalah refleksi dari hubungan Islam dan Barat. Sepanjang sejarah, hubungan ini kerap mengalami pasang surut. Baiknya hubungan di antara kedua peradaban yang kontras ini dirintis oleh beberapa sarjana yang berupaya memadukan filsafat Barat (lebih tegasnya filsafat Eropa) dengan filsafat Islam. Upaya ini kelak melahirkan ilmu pengetahuan modern (Yunanto dkk., 2003: 25). Selanjutnya dikatakan bahwa klimaks dari perpecahan Islam dengan Barat terjadi akibat bangsa-bangsa Eropa melakukan kolonisasi terhadap Negaranegara di Asia dan Afrika yang sebagian di antaranya berpenduduk Muslim. Kedua, hubungan Islam dan Kristen yang selalu mengalami ketegangan pada masa lalu, karena Kristen dianut oleh sebagian besar orang Eropa, dan konflik Islam dengan Kristen terjadi pada masa pengusiran orang-orang Islam dari Spanyol dan tragedi Perang salib. Sebab ketiga adalah: Ideologisasi agama akan melahirkan pemikiran perlunya mendirikan Negara Islam, dengan keyakinan politik yang berakhir dengan kesimpulan bahwa Nabi Muhammad saw. tidak sekedar berkedudukan sebagai utusan Allah, tetapi juga berkedudukan sebagai kepala Negara dan pemimpin politik di zaman sekarang. Jika ditelusuri lebih mendalam pandangan Islam politik bahwa Nabi Muhammad saw. juga berkedudukan sebagai kepala Negara yang membangun Daulah Islamiyah bahwa (pandangan) itu datang dari kalangan orientalis Barat, seperti diungkapkan oleh W. Montgomery Watt mengenai Negara
Islam yang pernah didirikan oleh Nabi Muhammad saw. merupakan suatu Negara penduduknya terdiri dari percampuran berbagai suku bangsa Arab (Ramly, 2006.268-269; Watt, 1969: 53).

Negara Mesir menjadi jajahan Inggris sejak gagalnya Revolusi Arab yaitu pada 14 September 1882, saat itu merupakan hari pertama jatuhnya kota Kairo ke tangan Inggris (Aziz, 2005: 31). Zakariya Sulaiman Bayumi dalam disertasinya di Fakultas Ain Syams, Mesir tentang Al-Ikhwan Al-Muslimun wa AlJama'ah Al-Islamiyyah fi 'l-Hayah AsSiyasiyyah Al-Mishriyyah mengatakan bahwa penjajahan Inggris dengan segala konsekuensinya menjadi (salah satu, pen.) pemicu lahirnya Ikhwanul Muslimin (selanjutnya penulis sebut Al-Ikhwan), sebab keberadaan penjajah menjadi pembangkit sentimen keagamaan bagi rakyat Mesir dan mendorong mereka untuk melakukan perlawanan terhadap segala yang bersumber dari penjajah (Aziz, 2005: 45). Kecuali itu, lahirnya Al-Ikhwan juga disebabkan karena kebanyakan dari partaipartai politik yang ada di Mesir tidak mengakomodasi gagasan dan ide-ide rakyat Mesir, tetapi membawa pemikiran liberal Barat (id. 63) dan keluar dari syariat Islam.

Pada awal berdirinya, gerakan ini berpusat di kota Ismailiyah, tetapi pada tahun 1932 berpindah ke Kairo, saat ini pula tempat tinggal Imam Hasan Al-Banna pindah dari Ismailiyah ke Kairo. Pada saat awal berdirinya, anggota Al-Ikhwan hanya berjumlah sekitar 100 orang, tetapi di akhir tahun 1940-an anggota Al-Ikhwan telah mencapai 3000 orang. Pada awal perkembangannya, anggota gerakan ini menyebar ke berbagai Negara Arab seperti Suriah, Palestina, Yordania, Libanon, Irak, Yaman, dan sebagainya. Bahkan pada sekitar tahun 1948 gerakan Al-Ikhwan telah memiliki 2000 cabang dengan anggota dan simpatisan sekitar 500.000 orang yang mencakup hampir semua lapisan sosial di Mesir, termasuk dari kalangan angkatan bersenjata. Dan dewasa 
ini anggota dan simpatisan Al-Ikhwan telah menyebar ke berbagai wilayah di Asia seperti Indonesia, Malaysia, dan Jepang, bahkan menjadi lebih luas lagi ke berbagai penjuru dunia. Penyebaran AlIkhwan ke seluruh penjuru dunia dilakukan dengan sistem organisasi yang sangat rapi, bahkan gerakan ini kadang-kadang menyebar dengan nama lain, tetapi dengan suatu prinsip yang sama yaitu mengajak manusia ke dalam sistem Islam secara kaffah (menyeluruh) dan berupaya memukul mundur gerakan sekularisme.

Mula-mula gerakan ini menekankan pentingnya pembangunan sosial, pendidikan, dan moral kaum muslimin, jadi merupakan suatu usaha reformasi dari yang sudah lama dirintis tokoh-tokoh seperti Jamaluddin Al-Afghani, Muhammad Abduh, dan Rasyid Ridha. Tetapi sistem organisasi yang diterapkan oleh Al-Banna sedemikian praktis dan modern sehingga Al-Ikhwan merupakan organisasi yang secara konkret mencoba merealisasikan pikiran-pikiran pembaruan Jamaluddin Al-Afghani, Muhammad Abduh, dan Rasyid Ridha. Dan dalam pertumbuhan selanjutnya Al-Ikhwan menjadi tidak saja sebagai gerakan sosial dan pendidikan, tetapi juga kekuatan sosial-politik yang selalu diperhitungkan baik sebelum maupun sesudah revolusi Mesir 1952 (Rais, 1990: 75).

Sebelum organisasi Al-Ikhwan didirikan, sudah banyak gerakan/ organisasi dakwah yang didirikan, dan banyak memberikan warna pada pola dakwah Al-Ikhwan. Sehingga Al-Ikhwan dapat mengambil pelajaran berharga dari organisasiorganisasi yang mendahuluinya. Di antara berbagai organisasi terutama organisasi Islam yang amat berpengaruh terhadap berdirinya Al-Ikhwan adalah:

1) Gerakan Al-Wahabiyah; 2) Gerakan Al-Mahdiyah; 3) Gerakan As-Sanusiyah (Dekmejian, 1995: 16; . Aziz, 2005: 13).

\subsection{Gerakan Islam Radikal di Indonesia}

Penyebaran aliran Wahabi ke wilayah Nusantara dibawa oleh para haji yang baru pulang menunaikan rukun Islam kelima di Tanah Suci. Salah satunya melalui kaum Padri di Minangkabau yang dikembangkan tiga tokoh.Guru Besar Ilmu Sejarah Pemikiran Politik Islam pada Fakultas Adab IAIN Sunan Ampel Surabaya, Abd A'la, dalam pidato ilmiahnya mengungkapkan, ketiga tokoh yang tertarik dengan ajaran Wahabi itu adalah Haji Miskin dari Lu(h)ak Agam, Haji Abdur Rahman dari Piobang, bagian dari Lu(h)ak Limah Puluh Kota, dan Haji Muhammad Arief dari Sumanik, Batusangkar. "Sekembali dari Tanah Suci antara tahun 1803 dan 1804, Haji Miskin membawa ide bahwa perubahan total dalam masyarakat Minangkabau yang (dalam anggapannya) tidak sesuai dengan ajaran Alquran harus dilakukan melalui kekuatan sebagaimana dilakukan kaum Wahabi di Arab," tutur Prof A'la. Secara prinsip, kata Prof A'la, ide itu juga diamini oleh dua Haji yang lain. Sejak saat itu, gerakan kaum Padri mulai berusaha menancapkan pengaruhnya di berbagai daerah Minangkabau. Menurut dia, dalam upaya melakukan perubahan radikal, gagasan-gagasan tiga Haji itu mendapat tantangan keras dari guru-guru Tarekat Syattariyah. Usaha ketiga tokoh itu dan tidak dapat berjalan mulus seperti yang diharapkan. Menurut Prof Abd A'la, Haji Miskin misalnya, yang berasal dari Empat Angkat, Agam, tidak mampu meyakinkan Tuanku Nan Tuo, tokoh agama yang dulu menjadi teman seperdagangan sebelum berangkat ke Tanah Suci mengenai pola keagamaan yang akan dikembangkan. "Karena itu ia pergi ke Enam Kota, dan tinggal di Pandai Sikat. Di sini ia tidak begitu berhasil melakukan pembaharuan, dan terpaksa angkat kaki menuju Kota Lawas. Setelah mengalami beberapa kesulitan, akhirnya Haji Miskin bersama Kaum Padri berhasil mengenalkan pembaharuan mereka," papar A'la. Setelah itu, seluruh Enam Kota termasuk Kota Lawas dan Pandai Sikat menjadi benteng kaum Padri, setelah sebelumnya mereka melakukan pembakaran terhadap balai di 
Kota Lawas. Menurut Prof Abd A'la, pada awalnya gerakan Padri merupakan gerakan sporadis yang ada di berbagai tempat di Minangkabau. Dengan berlalunya waktu, para pemukanya saling berhubungan satu dengan yang lain sehingga gerakan Padri menjadi satu komunitas yang relatif terorganisir. Kekuatan kaum Padri mulai menemukan pijakan yang kokoh ketika pada 1811. Saat itu, Haji Miskin sampai di Bukit Kamang dan bertemu dengan Tuanku Nan Renceh, pemuka agama yang juga bervisi sama. Di sana mereka sepakat merencanakan pembaharuan masyarakat secara total. Mereka didukung oleh enam pemuka lain yang kemudian disebut Harimau Nan Selapan (karena jumlahnya delapan orang). Mereka adalah Tuanku di Kubu Sanang, Tuanku di Ladang Lawas, Tuanku di Padang Luar, Tuanku di Galung, Tuanku di Koto Ambalan, dan Tuanku di LubukAur. Selanjutnya, pada tahun 1813 Tuanku Lintau ikut bergabung dan menjadi penganut fanatik ajaran-ajaran kaum Padri.Sejatinya jauh sebelum itu, sekitar tahun 1807, Tuanku Muda dari Alahan Panjang dan nantinya disebut Tuanku Imam Bonjol ikut memperkuat posisi kaum Padri. Melalui tangan dingin para pemuka itu, kaum Padri sebagaimana akan dijelaskan nanti berkembang menjadi gerakan yang menyebar di alam Minangkabau dengan segala karakteristiknya dan nantinya menguasai seluruh nagari di sana. "Sejarah mencatat, kaum Padri tidak hanya melakukan pembaharuan keislaman di daerah Minangkabau semata. Kelompok ini juga melakukan islamisasi ke Tapanuli Selatan yang terletak di utara alam Minangkabau dan daerah-daerah sekitarnya," ujar Prof Abd A'la. Setelah itu, paham Wahabi masih berkembang pesat di Indonesia. Pengikut manhaj dakwah Muhammad bin Abdul Wahab sangat sangat pesat pekembangannya. Di era prakemerdekaan dan pascakemerdekkaan, pemikiran Wahabi banyak memengaruhi pemikiran Muhammadiyah, Persis, dan Al-Irsyad. Namun demikian, kehadiran Wahabi setelah tahun 90-an, semakin merebak dan fenomenal dengan aliran Wahabi terbaru yang menamakan diri sebagai jamaah salafiyah. Di Indonesia, gerakan salafi terpecah ke dalam beberapa kelompok. Kelompok-kelompok Salafiyah Sejatinya, para pengikut Muhammad bin Abdul Wahab menamakan diri mereka dengan Salafiyun. Namun, para penentang dan lawan dari gerakan ini menyebutnya sebagai Wahabi. Menurut para pengikut Abdul Wahab, sebutan Wahabiyun diberikan oleh kaum orientalis agar orang menjauhi gerakan ini.

(http://www.fiqhislam.com/index.php?opti on=com_content\&id=56195\&Itemid=366

20613).

Sesudah gerakan Padri, di Indonesia ada gerakan Islam yang revolusioner, yaitu gerakan Islam politik di Indonesia yang berideologi mendirikan Negara Islam. Gerakan ini muncul sejak diproklamasikannya NII (Negara Islam Indonesia) oleh DI/ TII. Dalam lintasan sejarah Indonesia, sebutan NII tidak dapat dilepaskan dari embrionya, yaitu Darul Islam, dan juga tokoh utamanya, yaitu Sekarmadji Maridjan Kartosuwirjo. Sebutan Darul Islam, dalam khazanah politik Indonesia dipakai untuk menunjuk pada suatu gerakan yang terjadi sesudah proklamasi kemerdekaan Republik Indonesia tahun 1945, gerakan ini dimaksudkan untuk merealisasikan citacita Negara Islam Indonesia, demikian dikatakan Van Dijk (1987:1).

Pada tahun 1980 sisa-sisa perjuangan DI/ TII Kartosuwiryo dibagi menjadi 7 faksi wilayah: 1) Wilayah Bogor, Serang, Purwakarta, dan Subang; 2) Cianjur, Purwokerto, Subang, Jakarta , Lampung; 3) Garut, Bandung, Surabaya, dan Jakarta; 4) Sumatera; 5) Jawa Tengah dan Yogyakarta; 6) Sulawesi Selatan; dan 7) Komandemen wilayah IX (selain wilayah yang tersebut di atas) (Yunanto dkk., 2003: 35).

Sebelum bergabung ke dalam TNI, Ali Murtopo pernah bergabung dengan laskar Hizbullah, salah satu unsur cikal 
bakal TNI. Danu M. Hasan adalah salah satu anak buah Ali di Hizbullah, ketika Ali masuk TNI Danu bergabung ke dalam DI/ TII dan menjadi orang kepercayaan Imam NII Kartosuwirjo. Danu M. Hasan sempat menjabat Komandemen DI/ TII se Jawa. Kelak, pasukan Danu berhasil ditaklukkan oleh Banteng Raiders yang dikomandani Ali Murtopo.

Perjalanan berikutnya, pasca penaklukan, terjalinlah hubungan yang lebih intensif antara Ali dengan Danu di dalam kerangka "membina mantan DI/ TII. Pada kasus persidangan kasus DI/ TII (tahun 1980-an) diketahui bahwa Ali Murtopo secara khusus menugaskan Kolonel Pitut Suharto untuk menyusup ke golongan Islam, antara lain dengan mengecoh Haji Ismail Pranoto (Hispran) di Jawa Timur. Di Jawa Barat, Pitut mendekati Dodo Kartosuwirjo dan gagal, tetapi berhasil membina Ateng Djaelani, yang kemudian di kalangan petinggi DI/ TII dianggap sebagai pengkhianat. Muncul kasus Komando Jihad yang merupakan muslihat Ali Murtopo, yang menggunakan istilah Islam justru untuk menjebak umat Islam (Awwas, 2008: 68).

Sebuah sumber lain menyebutkan tentang waktu yang paling awal dari gerakan Darul Islam dinyatakan bahwa Kartosuwirjo memproklamasikan Negara Islam Indonesia pada hari-hari sekitar menyerahnya Jepang. Menurut Alers, S.M. Kartosuwirjo memproklamasikan Darul Islam sejak 14 Agustus 1945. Tetapi ia menarik kembali proklamasinya sesudah mendengar pernyataan kemerdekaan oleh Soekarno dan Hatta pada tanggal 17 Agustus 1945. Mengenai kejadian ini, ada pihak yang meragukan karena berbagai alasan. Di antara alasan itu adalah: sangat tidak mungkin Kartosuwirjo memproklamasikannya di Jakarta; Jepang tidak akan mengizinkannya; tidak ada pemberitaan secara luas mengenai kejadian tersebut (Dijk, 1987: 5).

Gerakan Islam untuk pembelaan dan pemurnian Islam, hal ini dilakukan oleh FPI, Lasykar Jihad, FPIS, dan sebagaimnya. Adapun mengenai kelompok yang pertama, yaitu Gerakan Islam Revolusioner, kelompok ini dilakukan oleh MMI dan JAT. Ideologi MMI dan JAT tak banyak perbedaannya. Perbedaan pokok terletak tentang teknis kepemimpinan, pada MMI pemimpin dipilih secara periodik sedangkan pada JAT tidak mengenal system perodisasi dalam pemilihan kepemimpinan, jadi pemimpin itu dipilih seumur hidup. Pihak MMI mengatakan bahwa kepemimpinan yang dimaksud di sini bukanlah pemimpin negara atau khalifah, yang dipermasalahkan oleh Abubakar Baasyir adalah tentang kepemimpinan organisasi, padahal menurut Irfan, organisasi belum memiliki wilayah kekuasaan, maka boleh saja dilakukan secara periodik atau berkala dipilih secara musyawarah (Wawancara dengan Irfan, tokoh MMI Yogyakarta, 6 Agustus 2008).

Gerakan Islam lain yang perjuangannya setara dengan MMI dan JAT adalah kelompok Jamaah Islamiyah (JI) yang secara de Jure tak pernah ada di Indonesia, tetapi secara de facto dapat disebutkan bahwa gerakan tersebut ada di Indonesia. Sebagaimana dikutip oleh penelitian Yunanto dkk. tentang Gerakan Militan Islam: Di Indonesia dan di Asia Tenggara, bahwa Abdullah Sungkar yang memimpin (DI/ TII, pen.) wilayah Jawa Tengah, sebelum ia bergabung dengan NII, ia telah mendirikan sebuah kelompok yang diberi nama "Jamaah Islamiyah", yang kemudian berbaiat kepada salah seorang pimpinan NII, H. Ismail Pranoto yang kelak terkenal di Solo (Lihat Karen Armstrong dan Abdul Hamid Al-Ghazali dalam Yunanto, dkk., 2003: 37-41). Perjuangannya di Jamaah Islamiyah ini, setelah Abdullah Sungkar (Surakarta, pen.) meninggal dilanjutkan oleh Abubakar Ba'asyir (Surakarta, pen.) sepulangnya dari pelariannya ke Malaysia. Agenda terbesar Abubakar Ba'asyir saat itu adalah menyelenggarakan Konggres I MMI. Tujuan penyelenggaraan konggres adalah untuk menyatukan berbagai elemen 
perjuangan Islam Indonesia, termasuk NII Faksi Non-Abdullah Sungkar.

Gerakan Islam lain yang yang dapat ditambahkan di sini adalah gerakan yang mewarnai kehidupan sosial keagamaan masyarakat di Ambon. Dimana kerukunan antar umat beragama yang sudah tertata harmonis di bawah ikatan budaya pela gandong menjadi hancur akibat kerusuhan pada tangagal 19 Januari 1999, dan berakibat pecahnya hubungan persaudaraan umat, sebagai klaim peperangan antar agama atau perang berbungkus agama. Pela Gandong adalah hubungan kekerabatan antar desa, tanpa melihat suku, golongan dan agama penduduknya. ( Yunanto, 2003: 98-99) Mereka mengikat tali persaudaraan penduduknya menyatu seperti dalam sebuah keluarga seperti halnya perjuangan hijrah yang dilakukan rasulullah bersamasama sahabatnya (kaum Muhajirin) dari Makkah ke Madinah, kemudianb membentuk satu kesatuan hidup bersama antar agama dan klan di bawah naungan ikatan Piagam Madinah.

Pecahnya budaya pela gandong berdampak pada pecahnya hubungan persaudaraan antar pemeluk agama, dalam hal ini adalah Islam dan Kristen yang berujung pada sikap saling menuduh, menyalahkan, dan memicau terjadinya sikap saling menyerang dan membunuh. Situasi yang sangat memungkinkan untuk melakukan tindakan radikal atas nama agama menjadi suatu keniscayaan yang tidak dapat dihindari akibat kuatnya provokasi dan kuatnya si dalang dalam memainkan aksi kerusuhan, hal ini disinyalir adanya kekuatan tentara yang memicu terjadinya peristiwa tersebut.

Kelompok-kelompok militan Islam mendasarkan perjuangan mereka atas argumentasi keagamaan dan kebangsaan. Argumentasi keagamaan dimaksud adalah bahwa perlawanan terhadap umat Kristen, termasuk peperangan yang dilakukan, memiliki dukungan tekstual keagamaan yang jelas, yaitu memerangi orang kafir yang memusuhi dan mengancam keberadaan umat Islam sebagai perang agama yang diperintahkan dalam $\mathrm{Al}$ Quran. (Yunanta, 2003: 101)

Radikalisme jenis ini nampaknya dapat dimasukkan ke dalam ketegori gerakan radikal Islam Kritis yaitu sikap tanggap terhadap situasi dan kondisi sosial beragama yang mengakibatkan adanya ketegangan.,kerusuhan, dan permusuhan. Hal ini bukan semata-mata karena didorong suatu cita-cita untuk menegakkan nilai-nilai Islam, atau bukan sebagai suatu perjuangan untuk penyebaran ajaran Islam, tetapi karena adanya perlawanan terhadap tatanan yang tidak adil, atau karena tekanan penguasa yang langsung bersinggungan dengan kepentingan masyarakat.

\section{Daftar Pustaka}

Abegebriel, A. Maftuh, dkk. 2004. dalam Negara Tuhan: The Thematic Encyclopaedia. Yogyakarta: SR-Ins Publishing.

2004: "Ada apa dengan dokumen JI". Dalam Negara Tuhan: The Thematic Encyclopaedia. Yogyakarta: SR-Ins Publishing.

Abdul Aziz, Jum'ah Amin. 2005. Auraaq min Taariikh Al-Ikhwaan AlMuslimuun: Dhuruuf An-Nasy'ah wa Syakhshiyah Al-Imaam Al-Mu'assis. (diterjemahkan oleh Bobby Herwibowo dengan judul: Masa Pertumbuhan dan Profil Sang Pendiri: Imam Syahid Hasan Al-Banna, Solo: Intermedia.

Azra, Azyumardi, 1996. Pergolakan Politik Islam: dari Fundamentalisme, Modernisme, hingga PostModernisme, Jakarta: Penerbit Paramadina. 
Choueiri, Youssef M.1990. Islam Garis Keras: Melacak Gerakan

Fundamentalisme. Yogyakarta:

Qonun.

2003. "Islam and Fundamentalism" dalam Roger Eatwell dan Anthony Wright (eds.) "Ideologi-Ideologi Politik Kontemporer", versi Indonesia (Jakarta: MediaTOR.

Dekmejian, R. Hrair, 1997. "Mulrtiple Faces of Islam" dalam Anders Jerichow dan Jørgen Bæk Simonsen (ed.),Islam in a Changing World: Europe and The Middle East, Great Britain: Curzon Press.

Dijk, Cornelis van, 1983. Darul Islam: Sebuah Pemberontakan. (Terj. Grafiti Pers). Judul asli: The Rebellion Under the Banner of Islam, diterbitkan oleh KITLV. Jakarta: Grafiti Pers.

Eickelman, Dale F. dan Piscatori, James. 1998. Ekspresi Politik Muslim. Jakarta: Mizan.

Hornby, AS et.al. 1987. Oxford Advance Leanner's Dictionary of Current English (revised and updated), New York, Toronto: Oxford University Press.

Husain, Mir Zohair, 1997. "The Ideologization of Islam: meaning, manifestations and causes" dalam Anders Jerichow dan Jørgen Bæk Simonsen (ed.), Islam in Changing World: Europe and Middle East, Great Britain: Curzon Press.

Kartodirdjo, $\quad$ Sartono, $\quad 1984$. "Pemberontakan Petani Banten 1988". Pustaka Jaya. Jakarta Harapan.
----------, Sartono 1997. "Metode Penggunaan Bahan Dokumen" dalam Koentjaraningrat, 1997. Metodemetode Penelitian Masyarakat. Jakarta: Gramedia Pustaka Utama.

Koentjaraningrat, 1997. Metode-metode Penelitian Masyarakat. Jakarta: Gramedia Pustaka Utama.

Loqman, Loebby. 1990. Analisis Hukum dan Perundang-Undangan Kejahatan terhadap Keamanan Negara di Indonesia, (Jakarta: Universitas Indonesia)

Mandzur, Ibnu Abul-Fadhl Muhammad. 1990. Lisaanul 'Arab. Beirut: Dar Shadir.

Mulyana W. Kusumah, 2002. Terorisme dalam Perspektif Politik dan Hukum, Jurnal Kriminologi Indonesia FISIP UI, vol 2 no III

Morris, William, 1973. The American Heritage Dictionary of English Language, Boston: Houghton Mifflin Co.

Ngatawi, 2002. Radikalisasi Gerakan Islam Simbolik FPI (Tesis Ilmu Sosial dan Politik). Jakarta: Program Pasca Sarjana Universitas Indonesia.

Poerbatjaraka, R.M.Ng, 1957. Kapustakan Djawi. Djakarta: Djambatan.

Rais, M. Amin, 1990. "Gerakan-gerakan Islam Internasional dan Pengaruhnya bagi Gerakan Islam Indonesia" dalam Percikan Pemikiran Fisipol UGM tentang Pembangunan, Yogyakarta: Fisipol UGM.

1990. Timur Tengah dan Krisis Teluk: Sebuah Analisa Kritis. Surabaya: Amarpress. 
Ramly, Andi Muawiyah, dkk. 2006. Demi Ayat Tuhan: Upaya KPPSI Menegakkan Syariat Islam. Jakarta: Opsi (Open Society Institute).

Roy, Oliver . 1996. Gagalnya Politik Islam. (edisi dalam bahasa Prancis berjudul: L'échec de l'islam politique,Edition du Seuil, 1992; dan edisi berbahasa Inggris berjuduL The Failure of the Political Islam,Harvard University Press, cet. 1. Jakarta: Serambi.

Suwarno, Peter. 2005. Resolving Religious Conflicts Through Expanding InterReligious Communication: Issues and Challenges, Jurnal Al Jami'ah, Vol 43 , No 2, 2005/1426 H

Syarkun, Mukhlas dan Ghorara, W. 2004. "Dunia Islam dalam Benturan Kepentingan dan Peradaban", dalam
Negara Tuhan: The Thematic Encyclopaedia, Yogyakarta: SR-Ins Publishing.

Watt, William Montgomery, 1969. Muhammad, Prophet and Statesman, Oxford: Oxford University Press.

Wijaya, M.Yusuf, 2001. "Visi-visi Pemikiran Keislaman: Upaya Klasifikasi Pemikiran Keislaman Timur Tengah" dalam Islam Garda Depan: Mosaik Pemikiran Islam Timur Tengah. Editor M. Aunul Abied Shah et.al. Bandung: Mizan.

Yunanto S. dkk. 2003. Gerakan Militan Islam: di Indonesia dan di Asia Tenggara. Jakarta: Friedrich-EbertStiftung (FES) dan The Ridep Institute. 